\title{
Effect of a size-selective biomanipulation on nutrient release by gizzard shad in Florida (USA) lakes
}

\author{
M.H. Schaus ${ }^{(1), \star}$, W.F. Godwin(2), L.E. Battoe ${ }^{(2)}$, M.F. Coveney ${ }^{(2)}$, E.F. Lowe ${ }^{(2)}$, \\ R. Roth ${ }^{(2)}$, W.W. Morris ${ }^{(1)}$, C. Hawkins ${ }^{(1)}$ \\ Received July 2, 2013 \\ Revised September 17, 2013 \\ Accepted October 2, 2013
}

Key-words: Dorosoma cepedianum, biomanipulation, size-structure, nutrient excretion

\section{ABSTRACT}

\begin{abstract}
Although fish removal for biomanipulation is often highly size-selective, our understanding of the nutrient cycling effects of this size-selection is poor. To better understand these effects, we measured nutrient excretion by gizzard shad (Dorosoma cepedianum) of differing sizes from four central Florida (USA) lakes and combined these measures with gillnet biomass and size-structure data to compare lake-wide effects among lakes and years. Direct removal of $P$ in fish tissue ranged from $0.16-1.00 \mathrm{~kg} \cdot \mathrm{P} \cdot \mathrm{ha}^{-1} \cdot \mathrm{yr}^{-1}$. The estimated reduction in $P$ excretion due to harvest ranged from $30.8-202.5 \mathrm{~g} \cdot \mathrm{P} \cdot \mathrm{ha}^{-1} \cdot \mathrm{month}^{-1}$, with effects strongly tied to the biomass and size structure harvested. The amount of $P$ release prevented per $\mathrm{kg}$ of fish removed was lower in previously unharvested lakes, due to the initial removal of larger fish with lower mass-specific excretion rates. Gill net mesh size impacted the size distribution of harvested fish, with smaller fish that excrete more $P$ per gram being more vulnerable to smaller mesh sizes. In Lake Apopka, decreasing the mesh size by $1.3 \mathrm{~cm}$ yielded $P$ excretion reductions that were $10.7-15.1 \%$ larger. Fish harvesting to reduce internal nutrient cycling can be most effective by increasing total harvest and by harvesting smaller size classes over multiple years.
\end{abstract}

\section{RÉSUMÉ}

\section{Effet d'une biomanipulation sélective en taille sur la libération des éléments nutritifs par l'alose noyer dans des lacs de Floride (États-Unis)}

Mots-clés :
Dorosoma
cepedianum,
biomanipulation,
structure
en taille,
excrétion
d'éléments
nutritifs

Bien que l'enlèvement des poissons pour biomanipulation soit souvent très calibré, notre compréhension des effets sur le cycle des éléments nutritifs de cette sélection en taille est peu documentée. Pour mieux comprendre ces effets, nous avons mesuré l'excrétion des nutriments par l'alose noyer (Dorosoma cepedianum) de différentes tailles à partir de quatre lacs de Floride centrale (États-Unis) et combiné ces mesures avec la biomasse estimée aux filets maillants et les données de structure en taille pour comparer les effets à l'échelle du lac suivant les lacs et les années. Le retrait direct de $P$ dans les tissus des poissons variait de 0,16 à $1,00 \mathrm{~kg} \cdot P \cdot \mathrm{ha}^{-1} \cdot$ année $^{-1}$. La réduction de $P$ estimée par excrétion due à la récolte variait de 30,8 à $202,5 \mathrm{~g} \cdot \mathrm{P} \cdot \mathrm{ha} \mathrm{a}^{-1} \cdot \mathrm{mois}^{-1}$, avec des effets fortement liés à la biomasse et la structure en taille du retrait. La quantité de $P$ libérée évitée par $\mathrm{kg}$ de poisson prélevé était plus faible dans les lacs précédemment non pêchés, en

(1) Virginia Wesleyan College, Department of Biology, Norfolk/Virginia Beach, VA, USA

(2) St. Johns River Water Management District, Department of Water Resources, Palatka, FL, USA

* Corresponding author: mschaus@vwc.edu 
raison de la suppression initiale de gros poissons avec des taux d'excrétion de masse volumique inférieure. Le maillage des filets a impacté la distribution en taille des poissons pêchés, les petits poissons qui excrètent plus de $P$ par gramme étant plus vulnérables à des petits maillages. Dans le lac Apopka, la diminution de la taille des mailles de 1,3 cm a permis de réduire l'excrétion de $P$ de 10,7 à $15,1 \%$ en plus. Le retrait de poissons afin de réduire le cycle nutritif interne peut être plus efficace en augmentant la récolte totale et en récoltant des classes de plus petite taille sur plusieurs années.

\section{INTRODUCTION}

Biomanipulation through fish harvesting has been used to improve water quality in many lakes (Meijer et al., 1999; Søndergaard et al., 2008). Removals of planktivorous fishes can increase the abundance of larger zooplankton and decrease phytoplankton via trophic cascade mechanisms (Carpenter et al., 1987), but some of the response can be due to changes in nutrient cycling (Vanni and Layne, 1997). The removal of omnivorous and benthivorous fishes can decrease sediment resuspension, directly remove nutrients in fish tissue, and decrease nutrient excretion by fish (Lamarra, 1975; Matsuzaki et al., 2007; Schaus et al., 2010). These processes can interact to lower turbidity and potentially increase macrophyte abundance, which is often linked to the effectiveness of lake restoration (Scheffer, 2001; Søndergaard et al., 2008). Ideally, an intense fish manipulation can shift the ecosystem from a highly productive phytoplankton dominated state to a stable clear water state, with decreased phytoplankton, increased zooplankton and increased macrophytes (Scheffer et al., 1993; Søndergaard et al., 2008).

Reductions of fish stocks can be conducted with non size-selective means, such as pond draining or rotenone, or by size-selective means, such as piscivore additions, trawls or gill nets (Drenner and Hambright, 1999). Many types of commercial fishing gear are highly selective for larger size classes, shifting the population toward one dominated by smaller fish (Hall et al., 2007; Catalano and Allen, 2011b). Utilizing commercial fisheries for biomanipulation favors the rapid removal of a large biomass in a cost-effective manner, regardless of any effects on size structure. This is often desirable, as biomanipulation more frequently improves water quality in cases with extensive fish removals, especially where $80 \%$ of the fish biomass or $>200 \mathrm{~kg} \cdot \mathrm{ha}^{-1}$ can be removed within a three year period (Hansson et al., 1998; Meijer et al., 1999; Søndergaard et al., 2008). Despite the strong size-selective nature of many biomanipulation efforts relying on commercial fishing, little is understood about the impact that this shift may have on nutrient cycling (Hall et al., 2007). Smaller fish typically have higher mass-specific nutrient excretion rates (Lamarra, 1975; Brabrand et al., 1990; Gido, 2002), so size-selective harvest at similar biomass levels could have important consequences for nutrient cycles.

The fish biomass of lakes and reservoirs in the midwestern and southern USA is often dominated by gizzard shad (Dorosoma cepedianum), especially in eutrophic to hypertrophic lakes (Bachmann et al., 1996; Allen et al., 2000). Because of its abundance and its omnivorous diet, gizzard shad is a good candidate for biomanipulation to improve water quality. The St. Johns River Water Management District (hereafter SJRWMD) used commercial fishers to remove $>7.4$ million kg of gizzard shad from Lake Apopka (1993-2009) and 1.2 million kg from Lake Griffin (2002-2008). The Lake Apopka harvest included both seasonal (Jan.-May) harvests where commercial fishers were paid a subsidy by SJRWMD as an incentive to increase the harvest, as well as a smaller year-round unsubsidized harvest. The SJRWMD also has conducted experimental harvests in Lakes Denham (1990-1992; Godwin et al., 2011) and Dora (2005-2006; Catalano and Allen, 2011a), so the nutrient effects of fish harvests can be compared among lakes and years.

Our previous work (Schaus et al., 2010) estimated nutrient effects of harvest in Lake Apopka during 1993-2005 using direct excretion measurements of $N$ and $P$ and scaling these up to 


\section{Table I}

Physical and chemical characteristics of the four lakes where excretion measures were conducted. The fish harvest in Lake Dora included the adjacent Beauclair basin, so that basin is included in the measures reported for Lake Dora. Bathymetry data are taken from Coveney et al. (2005) and Fulton (1995), combining the data for Dora and Beauclair. Water quality data are mean values $( \pm S D)$ for samples collected during 2002-2009 by SJRWMD from 3 stations per lake (1 station for Lake Eustis). Water quality data are fully reported in the Florida Atlas of Lakes (http://www.wateratlas.usf.edu/AtlasOfLakes/Florida/).

\begin{tabular}{|l|c|c|c|c|c|c|c|}
\hline Lake & $\begin{array}{c}\text { Area } \\
(\mathrm{ha})\end{array}$ & $\begin{array}{c}\text { Mean } \\
\text { depth } \\
(\mathrm{m})\end{array}$ & $\begin{array}{c}\text { Mean } \\
\text { Secchi } \\
\mathrm{depth}(\mathrm{m})\end{array}$ & $\begin{array}{c}\text { Mean } \\
\mathrm{Chl} \text { a } \\
\left(\mathrm{\mu g} \cdot \mathrm{L}^{-1}\right)\end{array}$ & $\begin{array}{c}\text { Mean } \\
\text { total } N \\
\left(\mu \mathrm{g} \cdot \mathrm{L}^{-1}\right)\end{array}$ & $\begin{array}{c}\text { Mean } \\
\text { total } P \\
\left(\mu \mathrm{g} \cdot \mathrm{L}^{-1}\right)\end{array}$ & $\begin{array}{c}\text { Harvested } \\
(\text { years })\end{array}$ \\
\hline Apopka & 12500 & 1.65 & $\begin{array}{c}0.31 \\
( \pm 0.08)\end{array}$ & $\begin{array}{c}66 \\
( \pm 29)\end{array}$ & $\begin{array}{c}4573 \\
( \pm 1658)\end{array}$ & $\begin{array}{c}129 \\
( \pm 64)\end{array}$ & $1993-2009$ \\
\hline Dora/Beauclair & 2213 & 2.82 & $\begin{array}{c}0.36 \\
( \pm 0.06)\end{array}$ & $\begin{array}{c}111 \\
( \pm 34)\end{array}$ & $\begin{array}{c}3495 \\
( \pm 601)\end{array}$ & $\begin{array}{c}73 \\
( \pm 35)\end{array}$ & $2005-2006$ \\
\hline Eustis & 3139 & 3.46 & $\begin{array}{c}0.61 \\
( \pm 0.28)\end{array}$ & $\begin{array}{c}48 \\
( \pm 29)\end{array}$ & $\begin{array}{c}2301 \\
( \pm 493)\end{array}$ & $\begin{array}{c}47 \\
( \pm 16)\end{array}$ & Unharvested \\
\hline Griffin & 3809 & 2.36 & $\begin{array}{c}0.48 \\
( \pm 0.27)\end{array}$ & $\begin{array}{c}72 \\
( \pm 44)\end{array}$ & $\begin{array}{c}2811 \\
( \pm 645)\end{array}$ & $\begin{array}{c}56 \\
( \pm 18)\end{array}$ & $2002-2008$ \\
\hline
\end{tabular}

the entire harvest based only on the mean mass of gizzard shad collected that was vulnerable to gill nets, and not the specific size structure of the fish removed. This study builds on our previous work by comparing nutrient excretion by gizzard shad among four central Florida lakes (Table I), then comparing nutrient effects of fish harvest (2002-2009) for three of these lakes that have undergone intensive fish removals, based on our excretion measures, the size distributions of fish removed by the biomanipulation during each lake-year, and the mesh sizes permitted for fishing at that time. Doing so will enable us to determine a) how broadly applicable the results of our excretion measures are, b) the range of nutrient effects observed in this type of fish harvest, c) the degree to which shifts in size structure of the harvest can alter nutrient cycling by fish, and d) the degree to which mesh size can impact the nutrient effect of the fish harvest.

\section{MATERIALS AND METHODS}

We directly measured nutrient release by 168 gizzard shad collected from Lakes Apopka ( $n=58)$, Dora $(n=46)$, Eustis $(n=38)$ and Griffin $(n=26)$, using methods similar to those of other studies (Brabrand et al., 1990; Gido, 2002) and following the procedures detailed by Schaus et al. (2010). Gizzard shad were collected, placed in containers of pre-filtered lake water, and allowed to excrete for $30 \mathrm{~min}$; the difference in nutrient concentrations (before vs. after fish addition) was used to measure excretion. We sampled gizzard shad from all four lakes during Jan.-Feb., May, and Jul.-Aug. 2006, from all lakes except Lake Griffin in Mar. 2006, and only from Apopka and Dora during Mar. 2005. The 2005 Lake Apopka fish $(n=23)$ were included as a portion of those reported by Schaus et al. (2010), but are also reported here because of the intentional comparison to another lake. Fish used for excretion measurements spanned the size range available in each lake (7.7-860.0 g wet mass). The mean mass of fish used for excretion measurements from each lake ranged from $192.6 \mathrm{~g}$ in Lake Griffin to $251.5 \mathrm{~g}$ in Lake Apopka. Lake temperatures during the excretion measurements ranged from $15.6-31.8^{\circ} \mathrm{C}$, which is typical of the seasonal ranges observed in these lakes.

We used ANCOVA (SPSS 15, General Linear Model) to determine whether there were between-lake differences in $N$ and $P$ excretion rates and ratios, comparing lake as the factor, with log wet mass of individual fish and temperature as covariates. Excretion rates and wet mass data were log transformed prior to analysis to normalize the variance. Temperature was not log transformed due to the linear relationship between temperature and the logarithm of excretion rates (Wen and Peters, 1994; Schaus et al., 1997). Where nutrient release rates differed significantly among lakes $(N)$, follow-up multiple regression was conducted on the data from each lake to allow comparison of regression coefficients for mass and temperature 
among lakes with previously published measures (Schaus et al., 1997, 2010; Gido, 2002). Where nutrient release did not differ significantly among lakes ( $P$ and the N:P ratio), we conducted follow-up multiple regressions on data pooled from all four lakes.

For lakes where the SJRWMD has recently conducted fish removals (Apopka, Dora, and Griffin), we combined a length-frequency distribution from commercial gill nets sampled for SJRWMD in each lake-year (annual sample sizes were $n=300-1400$ fish for Lake Apopka, $n=501-682$ for Lake Dora, and $n=100-650$ for Lake Griffin) with length-mass regressions for gizzard shad collected by gill nets and/or electrofishing from each lake ( $n=132$ fish for Apopka WM $=0.000005 \times \mathrm{TL}^{3.116} ; n=719$ for Dora $\mathrm{WM}=0.0000015 \times \mathrm{TL}^{3.358}$; and $n=323$ for Griffin WM $=0.00000058 \times \mathrm{TL}^{3.503}$; $\mathrm{WM}=$ wet mass in $\mathrm{g}, \mathrm{TL}=$ total length in $\mathrm{mm})$. This enabled us to determine the wet mass of a fish and the proportion of harvested biomass in each $1 \mathrm{~cm}$ size grouping. Direct $P$ removals (in fish tissue) due to harvest were estimated as $0.824 \%$ of the wet biomass harvested because Higgins et al. (2006) and Pilati and Vanni (2007) both observed that gizzard shad body $\% P$ averaged $3.2 \%$ of dry mass for gizzard shad $>50 \mathrm{~mm}$ TL and for Florida gizzard shad, the dry mass averaged $25.76 \%$ of the wet mass (SJRWMD, unpublished data). Our estimates of excretion from each lake were combined with length-frequency data and mean monthly temperatures from that lake for May and June (typically the two months following the harvest) to estimate how the biomanipulation reduced $P$ excretion by fish in each lake-year. Instead of extrapolating this biomass reduction over an entire year (Schaus et al., 2010), we focused on the time period immediately after harvest, to minimize any potential seasonal shifts in population biomass, growth, and/or size structure and conservatively compare nutrient effects of harvest among lakes. We focused on lake-wide estimations of $P$ (and not $N$ ) because management of these lakes has focused on $P$ (Fulton and Smith, 2008), because other sources of $P$ have been reported for some of these systems (Coveney et al., 2002, 2005; Schaus et al., 2010) and because we observed that $N$ release differed significantly among lakes.

We examined the size-selective nature of the harvest by comparing the size distribution of fish harvested among years and the size distributions of fish harvested by nets of varying mesh size. The former was conducted in Lakes Apopka, Dora and Griffin during the years harvested, using the commercial net data, as described above. The effect of mesh size was examined during 2007-2009, using standard floating experimental gill nets $2.4 \mathrm{~m}$ deep with six $15.3 \mathrm{~m}$ long panels of $6.4,7.6,8.9,10.2,11.4,12.7 \mathrm{~cm}$ diameter stretched monofilament mesh, fished in lakes Apopka and Griffin by an independent observer, using the methods described by Catalano and Allen (2011a). Fish sampled on all dates during 2007-2009 were pooled within each lake ( $n>2000$ fish per lake), and the size distributions harvested by each mesh size were compared. Up until 2006, Lake Apopka was only permitted for fishing using gill nets with a diameter of at least $10.2 \mathrm{~cm}$ stretched mesh, whereas from 2007-2009, mesh as small as $8.9 \mathrm{~cm}$ was allowed. For 2007-2009, we compared size distributions and catch per unit effort (CPUE, by numbers and biomass) of commercial nets in Lake Apopka for the nets of different mesh sizes (8.9, 9.5 and $10.2 \mathrm{~cm} ; n=239-280$ nets sampled for CPUE per year; $n=52-804$ fish sampled in each mesh size during each year). The $9.5 \mathrm{~cm}$ mesh size included all nets between $9.1-9.9 \mathrm{~cm}$ stretch mesh, to simplify comparisons. All comparisons of net size distribution data were conducted using ANOVA with a Dunnett's T3 post test, because the variance was typically not homogeneous. Finally, we compared the impacts of these mesh sizes on nutrient cycling by calculating the nutrient effect using our excretion measurements and the size distributions caught in the different mesh sizes. We assumed an equivalent biomass harvested for the three mesh sizes, because CPUE by biomass for 8.9 and $10.2 \mathrm{~cm}$ mesh nets only differed significantly in 2008 .

\section{RESULTS}

The study lakes differed significantly in excretion of $N$ by gizzard shad, but not $P$ excretion or the N:P ratio (Table II). The ANCOVA model for $N$ explained much more of the amongfish variability $\left(R^{2}=0.646\right)$ than did the model for $P\left(R^{2}=0.395\right)$. Follow up regressions for 


\section{Table II}

ANCOVA results for nitrogen, phosphorus and the N:P ratio. For all statistical comparisons, $n=168$ fish and error df = 162. For nitrogen, Eustis differed from Dora and Griffin and Apopka differed from Griffin $(p<0.05)$. All other lake by lake comparisons did not differ significantly.

\begin{tabular}{|l|c|c|c|c|c|}
\hline \multicolumn{2}{|c|}{} & \multicolumn{4}{|c|}{$p$-values for } \\
\hline & $\begin{array}{c}\text { Overall } \\
\text { model } R^{2}\end{array}$ & Lake & Log wet mass & Temperature & Intercept \\
\hline Nitrogen & 0.646 & 0.037 & $<0.001$ & 0.001 & $<0.001$ \\
\hline Phosphorus & 0.395 & 0.237 & $<0.001$ & $<0.001$ & $<0.001$ \\
\hline N:P Ratio & 0.105 & 0.306 & 0.931 & 0.001 & 0.023 \\
\hline
\end{tabular}

\section{Table III}

Results of regression analyses for excretion measurements to predict gizzard shad $\mathrm{NH}_{4}-\mathrm{N}$ excretion in each system, based on Log wet mass (g), and temperature $\left({ }^{\circ} \mathrm{C}\right)$.

\begin{tabular}{|c|c|c|c|c|c|c|c|}
\hline & $n$ & $\begin{array}{l}\text { Overall } \\
\text { model } \\
p \text {-value }\end{array}$ & $\begin{array}{c}\text { Overall } \\
\text { model } \\
R^{2}\end{array}$ & Coefficient & \begin{tabular}{|c|}
$95 \%$ Lower \\
confidence \\
interval
\end{tabular} & $\begin{array}{c}95 \% \text { Upper } \\
\text { confidence } \\
\text { interval }\end{array}$ & $\begin{array}{c}\text { Coefficient's } \\
p \text {-value }\end{array}$ \\
\hline \begin{tabular}{|l} 
Lake Apopka \\
Intercept \\
Log wet mass \\
Temperature
\end{tabular} & 58 & $<0.001$ & 0.309 & $\begin{array}{c}-0.650 \\
0.514 \\
-0.002\end{array}$ & $\begin{array}{l}-1.366 \\
0.265 \\
-0.011\end{array}$ & $\begin{array}{l}0.066 \\
0.764 \\
0.008\end{array}$ & $\begin{array}{c}0.074 \\
<0.001 \\
0.735\end{array}$ \\
\hline \begin{tabular}{|c|} 
Lake Dora \\
Intercept \\
Log wet mass \\
Temperature \\
\end{tabular} & 46 & $<0.001$ & 0.910 & $\begin{array}{c}-1.613 \\
0.786 \\
0.016 \\
\end{array}$ & $\begin{array}{c}-1.832 \\
0.708 \\
0.010 \\
\end{array}$ & $\begin{array}{c}-1.394 \\
0.864 \\
0.023 \\
\end{array}$ & $\begin{array}{l}<0.001 \\
<0.001 \\
<0.001\end{array}$ \\
\hline \begin{tabular}{|c|} 
Lake Eustis \\
Intercept \\
Log wet mass \\
Temperature \\
\end{tabular} & 38 & $<0.001$ & 0.506 & $\begin{array}{c}-0.817 \\
0.572 \\
-0.001 \\
\end{array}$ & $\begin{array}{c}-1.904 \\
0.285 \\
-0.022 \\
\end{array}$ & $\begin{array}{l}0.270 \\
0.860 \\
0.020 \\
\end{array}$ & $\begin{array}{c}0.136 \\
<0.001 \\
0.921 \\
\end{array}$ \\
\hline \begin{tabular}{|l} 
Lake Griffin \\
Intercept \\
Log wet mass \\
Temperature
\end{tabular} & 26 & 0.298 & 0.100 & $\begin{array}{l}-0.263 \\
0.317 \\
0.005\end{array}$ & $\begin{array}{l}-1.405 \\
-0.094 \\
-0.012\end{array}$ & $\begin{array}{l}0.879 \\
0.729 \\
0.021\end{array}$ & $\begin{array}{l}0.639 \\
0.124 \\
0.568\end{array}$ \\
\hline
\end{tabular}

$N$ excretion in each lake showed significant effects of mass in all lakes except Lake Griffin, but only significant temperature effects in Lake Dora (Table III, Figure 1). The combined regression for $P$ indicated significant effects of mass and lake temperature (Table IV, Figure 2), whereas $N: P$ was only significantly affected by temperature (Table IV, Figure 3). $N$ and $P$ excretion showed a decline in mass-specific excretion with increasing fish mass, as regression coefficients (Tables III and IV) had $95 \%$ upper confidence intervals $<1$ in all cases. $P$ excretion increased with temperature, thus at warmer temperatures (Figure 2 - black and gray symbols) gizzard shad typically had higher excretion than at colder temperatures (white symbols), for fish of a specific mass.

Overall, the gizzard shad removals ranged from $19.1-121.6 \mathrm{~kg}$ wet mass $\cdot \mathrm{ha}^{-1} \cdot \mathrm{yr}^{-1}$, including both the seasonal (subsidized) harvest and year round (unsubsidized) harvest, with typical harvests of 30-60 kg wet mass $\cdot \mathrm{ha}^{-1} \cdot \mathrm{yr}^{-1}$ and direct $P$ removal of $0.24-0.48 \mathrm{~kg} \mathrm{P} \cdot \mathrm{ha}^{-1} \cdot \mathrm{yr}^{-1}$ (Table V). The size distribution of the harvest from Lake Apopka fluctuated among years, with decreases in size observed following the shift to smaller mesh sizes in 2007 (Figure 4). The harvest in Lake Dora removed larger fish during 2005, with a significant shift toward smaller sizes during the second year of harvest (Figure 4). The harvests from Lake Griffin also showed a significant shift downward in size over time (Figure 4). Differences in direct (fish removal) and indirect (excretion) nutrient effects of harvest (Table $\mathrm{V}$ ) across lake-years were most strongly tied to differences in harvest rate, with some effects of mean fish size, due to the higher excretion per gram of the smaller fish. 


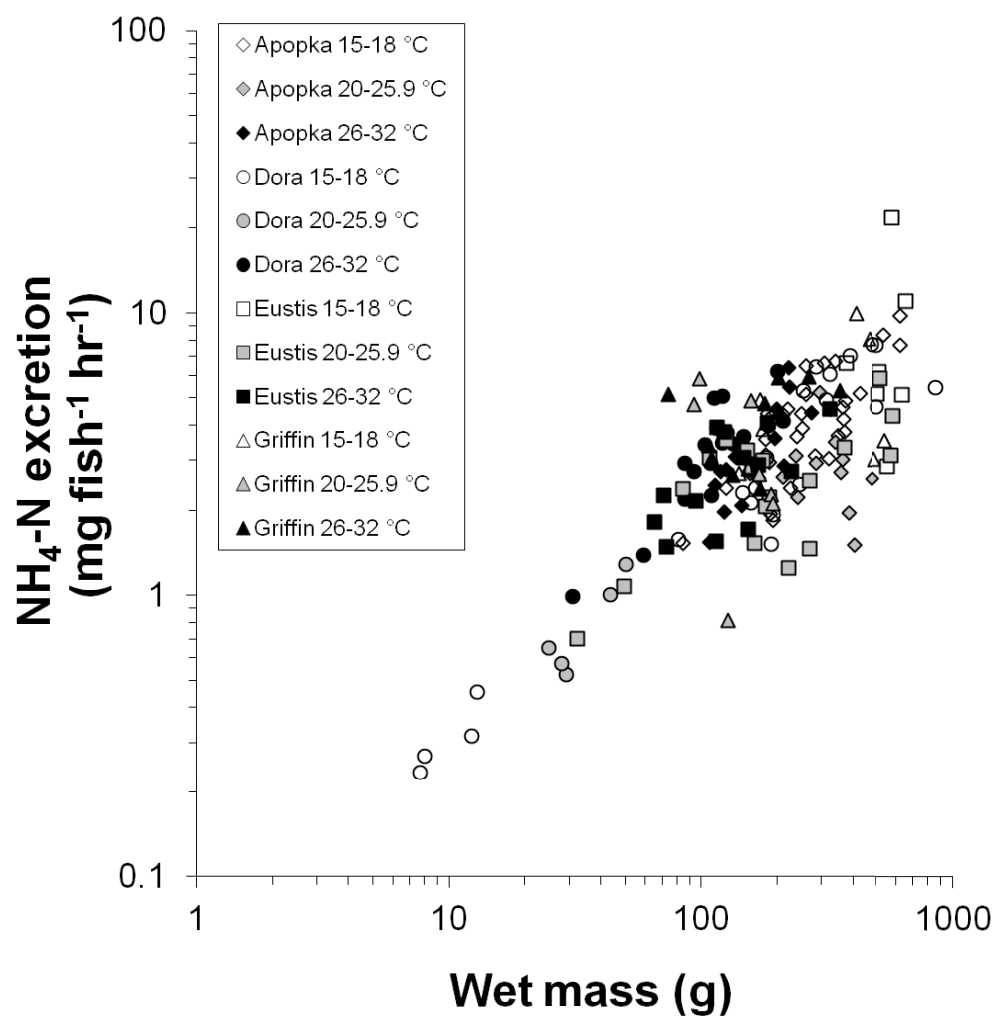

\section{Figure 1}

Excretion of $\mathrm{NH}_{4}-\mathrm{N}$ by gizzard shad from Lakes Apopka (diamond), Dora (circle), Eustis (square) and Griffin (triangle). For all lakes, measurements are grouped by water temperature into $15-18{ }^{\circ} \mathrm{C}$ (white), $20-25.9^{\circ} \mathrm{C}$ (gray), and $26-32{ }^{\circ} \mathrm{C}$ (black) groupings. ANCOVA results indicated significant differences among lakes $(p=0.037)$, and significant effects of Log wet mass $(p<0.001)$ and temperature $(p=$ $0.001)$.

\section{Table IV}

Results of regression analyses for excretion measurements to predict gizzard shad $P_{4}-P$ excretion and the N:P of excretion, based on Log wet mass $(\mathrm{g})$, and temperature ( $\left.{ }^{\circ} \mathrm{C}\right)(n=168$ for both models).

\begin{tabular}{|l|c|c|c|c|c|c|}
\cline { 2 - 7 } \multicolumn{1}{c|}{} & $\begin{array}{c}\text { Overall } \\
\text { model } \\
\text {-value }\end{array}$ & $\begin{array}{c}\text { Overall } \\
\text { model } \\
R^{2}\end{array}$ & Coefficient & $\begin{array}{c}95 \% \text { Lower } \\
\text { confidence } \\
\text { interval }\end{array}$ & $\begin{array}{c}95 \% \text { Upper } \\
\text { confidence } \\
\text { interval }\end{array}$ & $\begin{array}{c}\text { Coefficient's } \\
\text { p-value }\end{array}$ \\
\hline $\begin{array}{c}\text { Phosphorus } \\
\text { Intercept }\end{array}$ & $<\mathbf{0 . 0 0 1}$ & $\mathbf{0 . 3 7 9}$ & -2.550 & -3.006 & -2.095 & $<0.001$ \\
Log wet mass & & & 0.630 & 0.481 & 0.779 & $<0.001$ \\
Temperature & & & 0.038 & 0.028 & 0.048 & $<0.001$ \\
\hline N:P ratio & $\mathbf{0 . 0 0 1}$ & $\mathbf{0 . 0 8 5}$ & 32.663 & 5.060 & 59.720 & 0.018 \\
Intercept & & & 1.049 & -7.790 & 9.889 & 0.815 \\
Log wet mass & & & -1.068 & -1.642 & -0.493 & $<0.001$ \\
Temperature & & & \multicolumn{4}{c}{} \\
\hline
\end{tabular}

Experimental gill net samples from Lakes Apopka and Griffin (Figure 5) demonstrated that there was a substantial number of gizzard shad invulnerable to the $10.2 \mathrm{~cm}$ mesh gill nets most frequently used for these harvests, as experimental mesh sizes $<9 \mathrm{~cm}$ typically captured a greater number of fish, which were smaller than fish caught by larger mesh sizes. Commercial nets from Lake Apopka during 2007-2009 showed trends similar to the experimental net data, with smaller mesh sizes typically harvesting fish 3-4 cm smaller than those harvested by the larger mesh sizes (Figure 6). Within each year, the size distributions of fish caught in commercial nets differed significantly among mesh sizes (Dunnett's T3, $p<0.05$ ) for all pairwise comparisons except $9.5 \mathrm{~cm}$ vs. $10.2 \mathrm{~cm}$ during 2007. Smaller mesh nets typically caught a greater number of fish per standard fishing unit (SFU; $100 \mathrm{~m}$ of commercial 


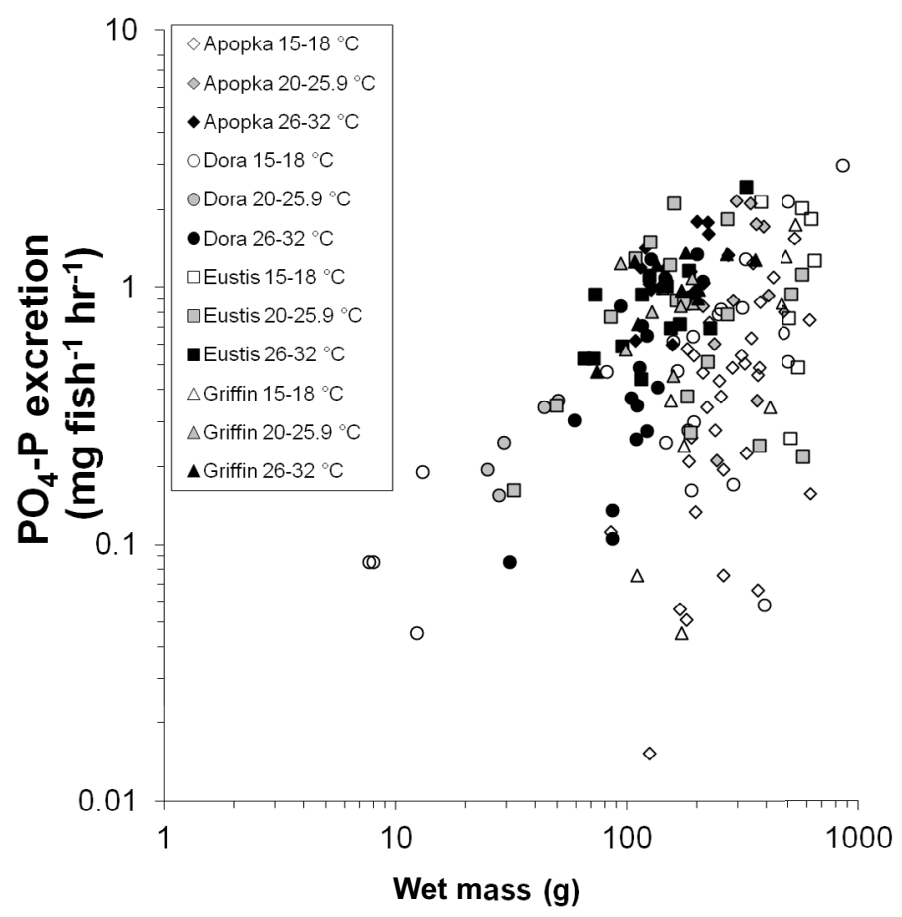

Figure 2

Excretion of $\mathrm{PO}_{4}-\mathrm{P}$ by gizzard shad from Lakes Apopka (diamond), Dora (circle), Eustis (square) and Griffin (triangle). For all lakes, measurements are grouped by water temperature into $15-18{ }^{\circ} \mathrm{C}$ (white), $20-25.9{ }^{\circ} \mathrm{C}$ (gray), and $26-32{ }^{\circ} \mathrm{C}$ (black) groupings. ANCOVA results indicated no significant differences among lakes $(p=0.237)$, with significant effects of Log wet mass $(p<0.001)$ and temperature $(p<0.001)$.

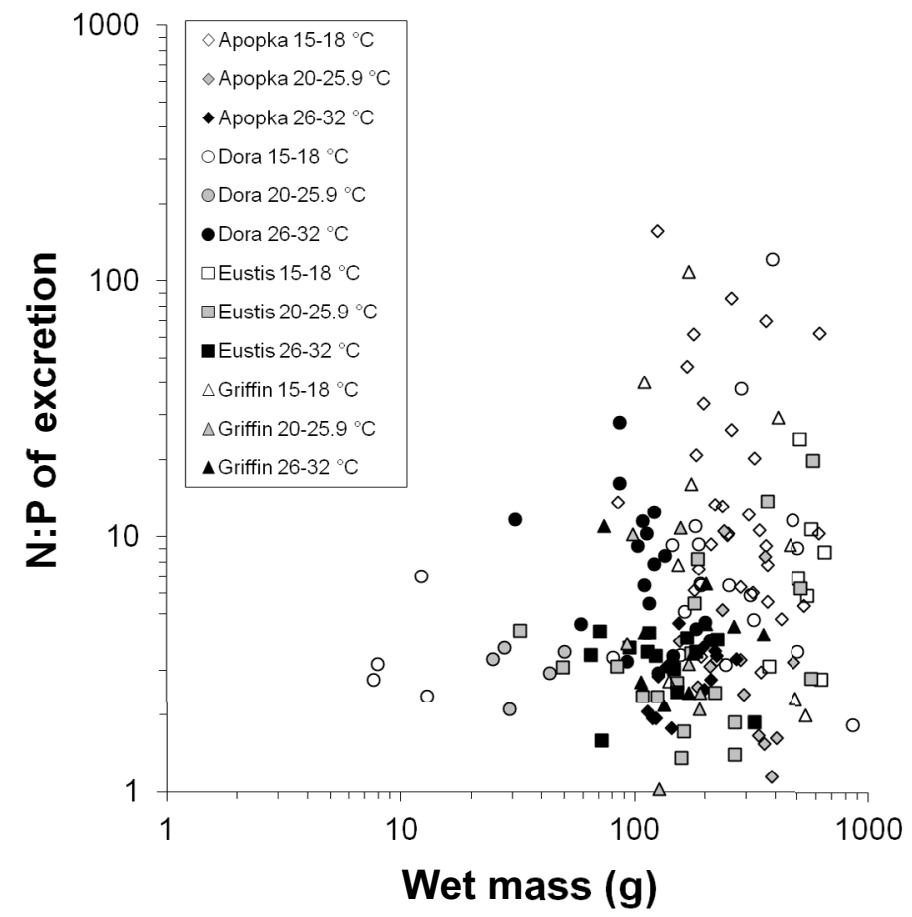

\section{Figure 3}

$N: P$ ratio of excretion by gizzard shad from Lakes Apopka (diamond), Dora (circle), Eustis (square) and Griffin (triangle). For all lakes, measurements are grouped by water temperature into $15-18^{\circ} \mathrm{C}$ (white), $20-25.9^{\circ} \mathrm{C}$ (gray), and $26-32^{\circ} \mathrm{C}$ (black) groupings. ANCOVA results indicated no significant effects of lake $(p=0.306)$ or Log wet mass $(p=0.931)$, but there was a significant temperature effect $(p=0.001)$. 
M.H. Schaus et al.: Knowl. Managt. Aquatic Ecosyst. (2013) 411, 13

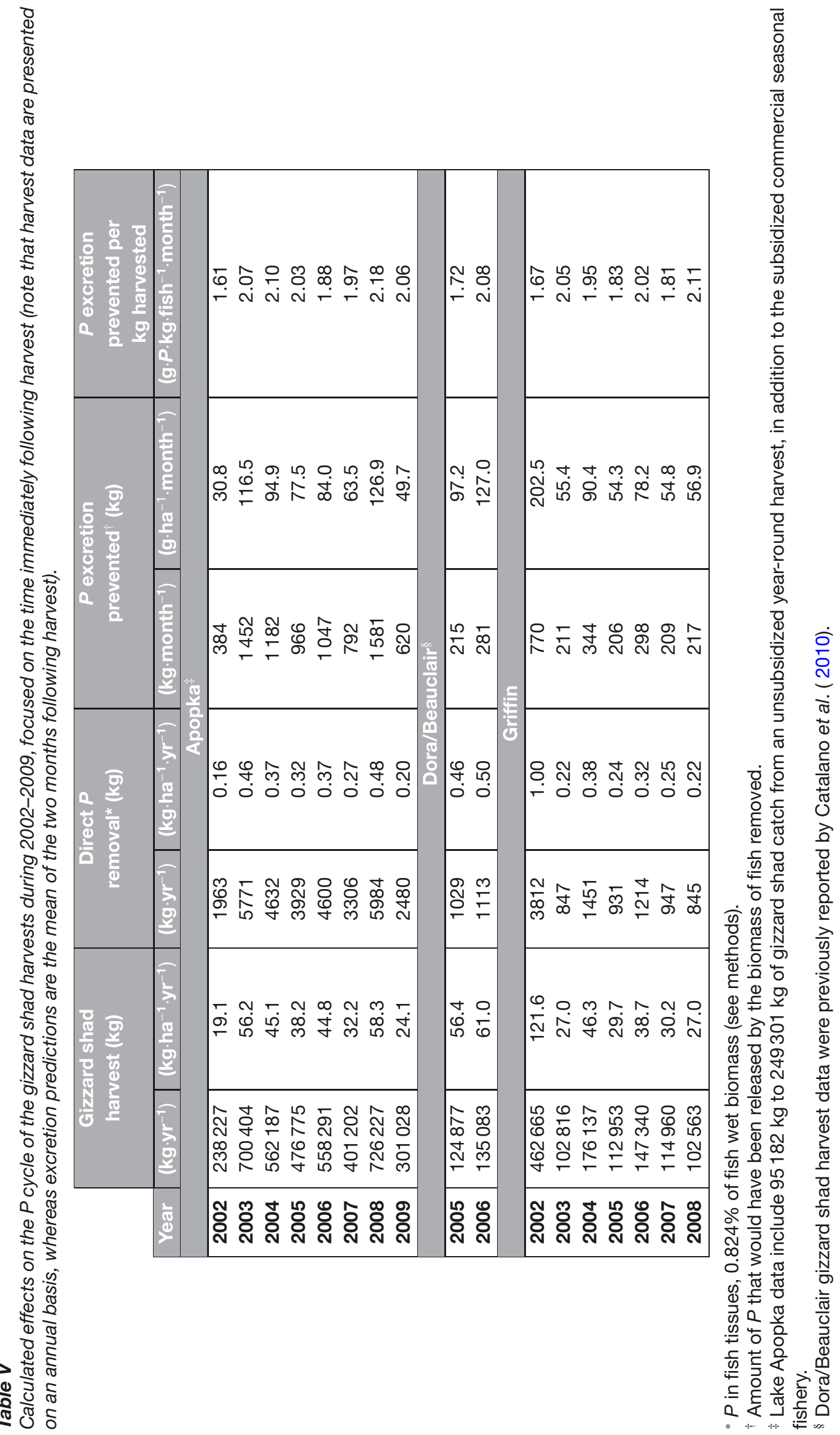



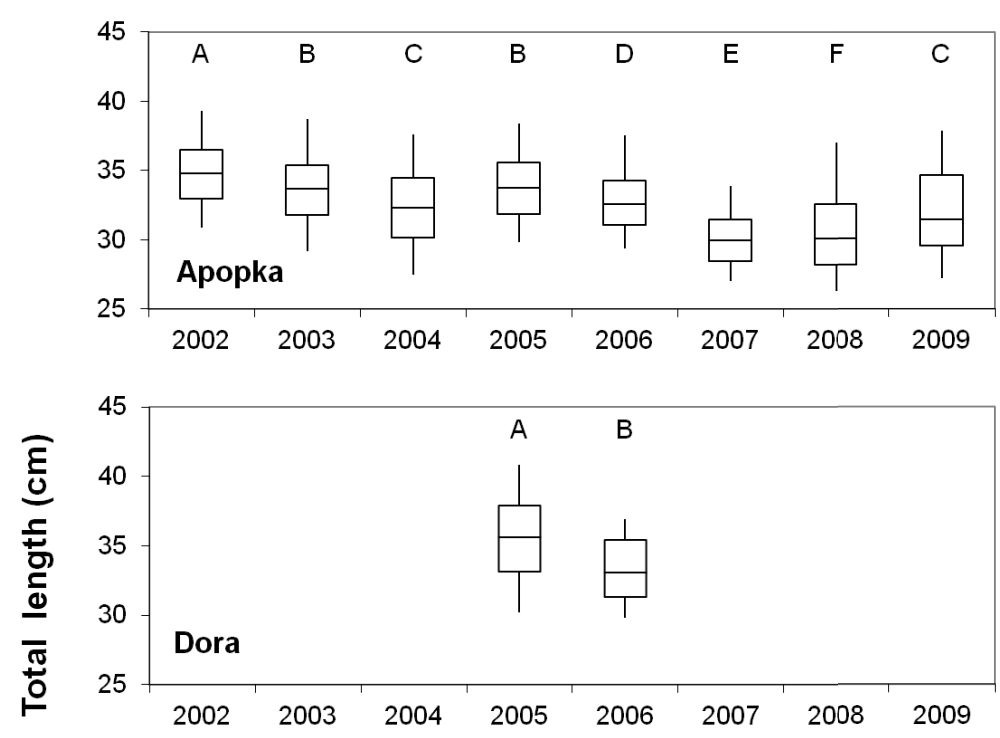

\section{Figure 4}

Total lengths (cm) of gizzard shad harvested in commercial nets from Lakes Apopka (top panel), Dora (middle panel) and Griffin (bottom panel) during 2002-2009 ( $n=100-1400$ fish sampled per lake-year). Boxes represent the interquartile ranges (25th, 50th and 75th percentiles) of fish harvested and the lines represent the 5th and 95th percentiles. Within each lake, the size distributions of fish differed significantly among years (Dunnett's T3, $p<0.005$ ) where indicated by different letters of the alphabet.

net fished for $1 \mathrm{~h}$ ) than larger mesh sizes, but the trends were less clear for the biomass harvested (Figure 7). During all years, the $8.9 \mathrm{~cm}$ nets always caught the same biomass (2007 and 2009) or greater biomass (2008) per SFU than the $10.2 \mathrm{~cm}$ nets (Figure 7). Combining the 2007-2009 Lake Apopka harvest data with the size distributions from commercial nets and our $P$ excretion predictions yielded $P$ recycling effects that varied substantially due to harvest and mesh size. The large harvest during 2008 doubled the nutrient effect, as expected (Figure 8). Within each year, the smallest mesh size $(8.9 \mathrm{~cm})$ had effects on excretion that were $10.7-15.1 \%$ greater than that of the largest mesh size $(10.2 \mathrm{~cm})$ typically used (Figure 8$)$, due to the harvest of smaller fish that have higher nutrient excretion per gram.

\section{DISCUSSION}

Gizzard shad $N$ and $P$ excretion showed similar allometric trends to previous studies, scaling with mass at approximately the $2 / 3$ power, with regression coefficients (Tables III- IV) relatively similar to those published for this species (Schaus et al., 1997, 2010; Gido, 2002). Although excretion can vary significantly among systems (Higgins et al., 2006; this study for $N$ ), similarity of the regression coefficients, especially for $P$ indicates that this approach may be broadly applicable to other systems. It is not fully clear why we observed small but significant differences in $N$ excretion among lakes. Pilati and Vanni (2007) observed that the N:P of excretion was more strongly tied to diet than to gizzard shad body N:P. Likewise Higgins et al. (2006) 

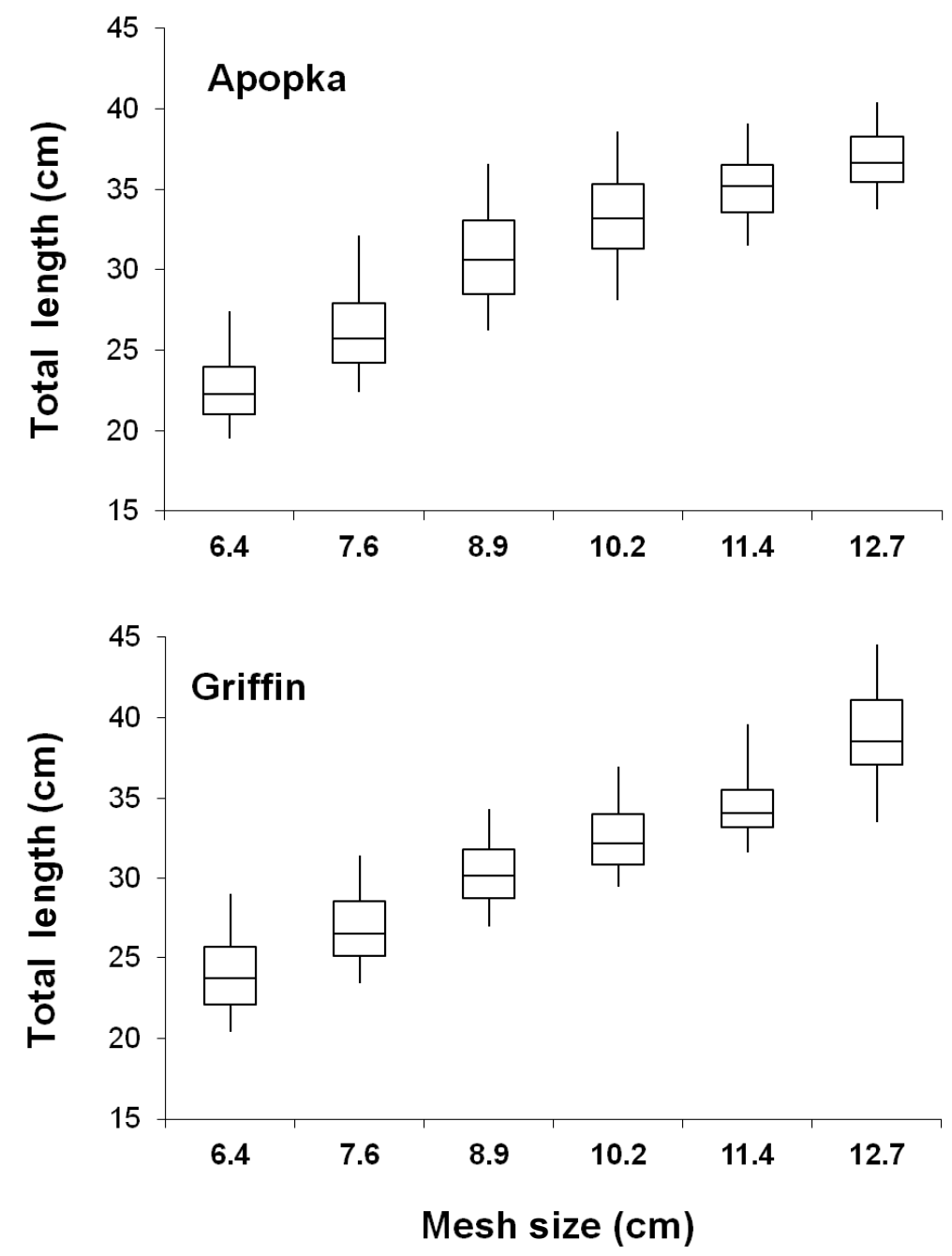

\section{Figure 5}

Total lengths (cm) of gizzard shad sampled in SJRWMD experimental gill net panels in Lake Apopka (top panel) and Lake Griffin (bottom panel) during 2007-2009. Mesh sizes are the maximum opening when stretched. Sample sizes ranged from $n=407-581$ fish per mesh panel for mesh sizes $<9 \mathrm{~cm}$ and $n=31-322$ fish per mesh panel for mesh sizes $>10 \mathrm{~cm}$. Boxes represent the interquartile ranges (25th, 50th and 75th percentiles) of fish harvested in that panel, and the lines represent the 5th and 95th percentiles. Within each lake, the size distributions differed significantly among mesh sizes (Dunnett's $T 3, p \leqslant 0.005)$ for all pairwise comparisons.

observed elevated $N$ excretion in lakes where the gut contents of gizzard shad were higher in $\mathrm{N}$. Thus it is possible that the $\% N$ of gizzard shad diets varied somewhat among lakes, or that some other source of inter-lake variability influenced excretion rates for $\mathrm{N}$.

Our findings indicate that the effects of fish removals on nutrient excretion can vary substantially due to the total mass and mean size removed (Table V, Figure 8). Both of these factors are strongly affected by mesh size. The potential effects on lake nutrient cycles also can be influenced by many other factors, including temperature, the unharvested size-distribution (Schmidt-Nielsen, 1975; Hall et al., 2007), diet (Vanni, 2002; Higgins et al., 2006; Pilati and Vanni, 2007), growth rate and fecundity (Kim and Devries, 2000; Schaus et al., 2002). Predictions of the potential benefits of fish harvest to the nutrient dynamics in a particular lake will depend on an understanding of these factors and how they may interact to impact the population over the short term and in the long term. We observed a stronger effect of water temperature on $P$ excretion than on $N$ excretion, leading to higher $P$ release and much lower $\mathrm{N}: \mathrm{P}$ during midsummer (Figures 2, 3). Thus the influence of fish on nutrient cycles could be 


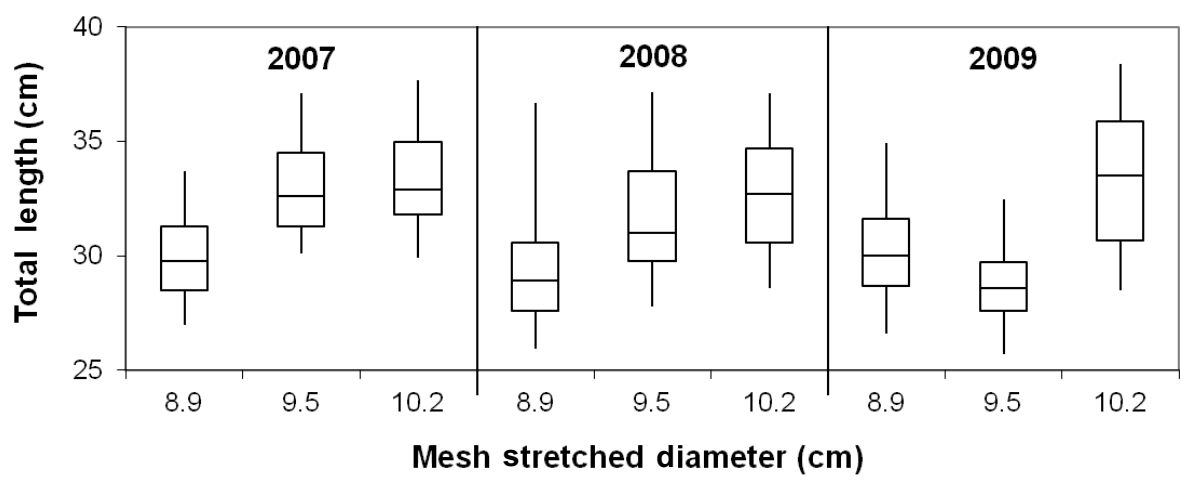

\section{Figure 6}

Total lengths $(\mathrm{cm})$ of gizzard shad sampled from Lake Apopka commercial nets of different mesh sizes during 2007-2009 ( $n=52-1278$ fish for each mesh size in each year). Boxes represent the interquartile ranges (25th, 50th and 75th percentiles) of fish harvested and lines represent the 5th and 95th percentiles. The $9.5 \mathrm{~cm}$ mesh size includes $9.1-9.9 \mathrm{~cm}$ mesh nets. Within each year, the size distributions caught differed significantly among mesh sizes (Dunnett's T3, $p \leqslant 0.005$ ) for all pairwise comparisons except $9.5 \mathrm{~cm}$ vs. $10.2 \mathrm{~cm}$ during 2007.

greater during warmer seasons and at warmer latitudes. However, biomanipulations may actually be less effective at warmer latitudes because of the longer growing season, increased omnivory and increased risk of algal blooms (Jeppesen et al., 2007, Kosten et al., 2009), which may offset the gains made by fish reductions. Clearly, more research on biomanipulation efforts in tropical and subtropical systems is needed (Jeppesen et al., 2007).

In fish removals such as this, commercial fishers typically use permissible gear that maximizes the biomass harvested per unit of time. Thus in Lake Apopka during 2007-2009, not all fishers used the smallest mesh size allowed, if larger mesh sizes were successful in harvesting fish. Our length-frequency data strongly suggest that it is advisable to select mesh sizes that are effective overall in terms of harvesting fish, but allow the removal of smaller size classes, as these fish have higher mass-specific rates of excretion. One clear case of this is in Lake Dora, where the second year of harvest removed only $8 \%$ more fish $\left(53.8 \mathrm{~kg} \cdot \mathrm{ha}^{-1}\right.$ in $2005 \mathrm{vs}$. $58.2 \mathrm{~kg} \cdot \mathrm{ha}^{-1}$ in 2006), but the amount of $P$ excretion prevented was $31 \%$ higher (Table V). This occurred with only a modest shift in size structure (from a median of $35.6 \mathrm{~cm}$ TL in 2005 to $33.1 \mathrm{~cm}$ TL in 2006, Figure 4). The nutrient effects of the 2007-2009 Lake Apopka gizzard shad harvests varied most substantially due to differences in total harvest (Table V). However, assuming equivalent biomass harvested by smaller and larger mesh sizes (Figure 7), the smaller mesh sizes had nutrient effects that were 10.7-15.1\% higher (Figure 8), because they harvested fish that were smaller. Likewise, in an enclosure experiment in Acton Lake, $\mathrm{OH}$, smaller gizzard shad enhanced phytoplankton and water column $P$ to a much greater extent than an equivalent biomass of larger fish (Schaus and Vanni, 2000), indicating the importance of fish size on nutrient cycling. By increasing the vulnerability of small gizzard shad, it may be possible to increase the overall fish harvest and the nutrient effect per $\mathrm{kg}$ of fish removed. Ideally, biomanipulations should seek to reduce all size classes, because many populations are dominated by small size classes that can avoid capture by commercial gill nets.

The overall effectiveness of a biomanipulation over the long term can be impacted by compensatory factors, such as increased growth, survival or fecundity. Reducing the biomass of larger fish can reduce the overall fecundity of the population, potentially delaying the recovery of the population to pre-harvest biomass levels. However, these reductions also reduce competition, potentially allowing a strong year class to more rapidly return the harvested population to the baseline level (Devries and Stein, 1990). In Walker County Lake, AL, the growth of age-0 gizzard shad was greatly increased following a selective fish harvest in Dec. 1995 (Kim and Devries, 2000). These individuals may have spawned as early as age-1, unlike later year classes of gizzard shad which were not as fast growing (Kim and Devries, 2000; Irwin et al., 2003). Unlike the current study, Walker County Lake was actively fertilized by the 

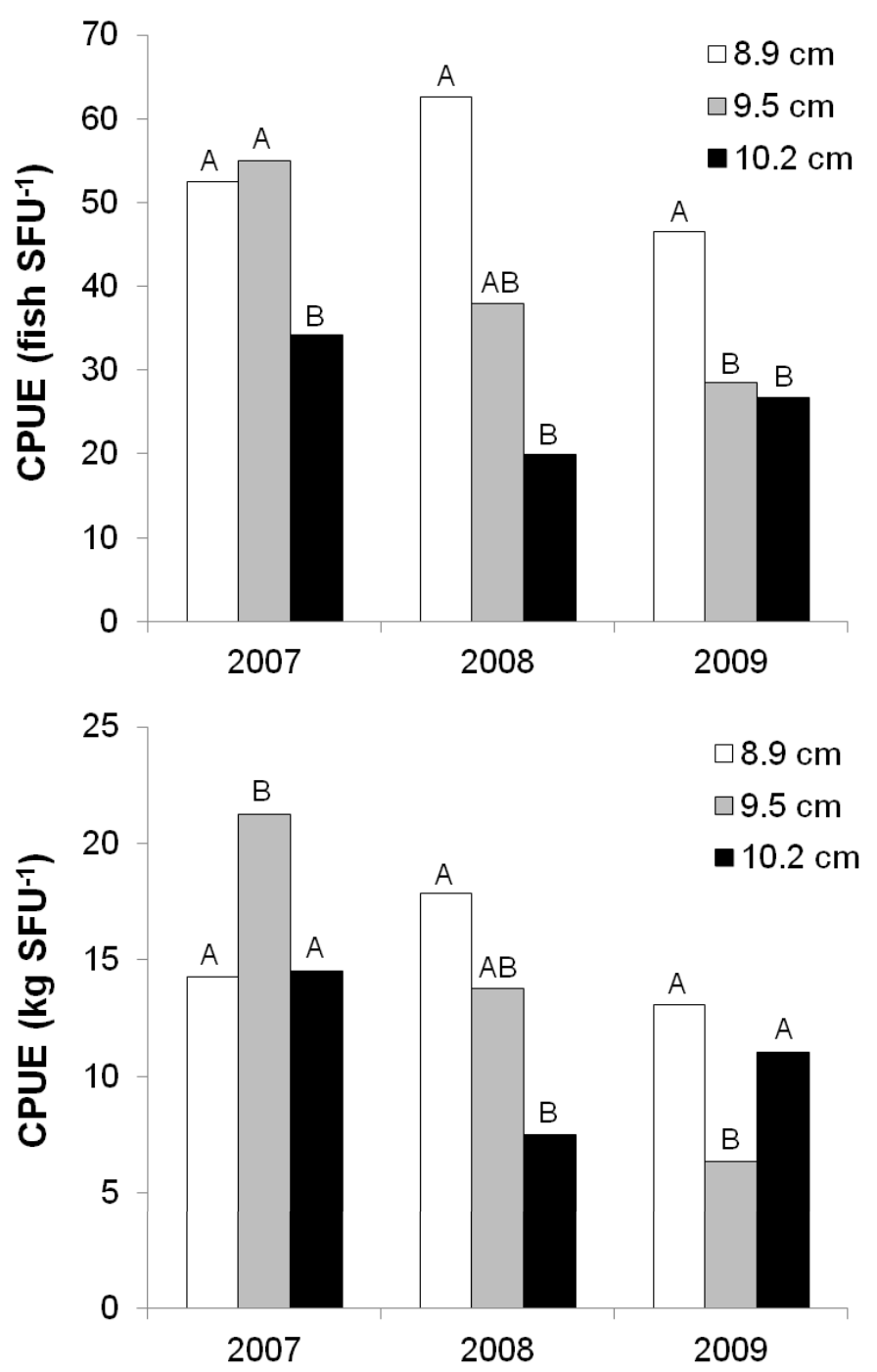

\section{Figure 7}

Catch per unit of fishing effort (CPUE) in 2007-2009 Lake Apopka commercial nets of differing mesh size, based on the number of fish (top panel) and biomass of fish (bottom panel) caught per standard fishing unit (SFU $=100 \mathrm{~m}$ of commercial net fished for $1 \mathrm{~h} ; n=173-1360$ SFU for each mesh size in each year). The $9.5 \mathrm{~cm}$ mesh includes nets $9.1-9.9 \mathrm{~cm}$. The $10.2 \mathrm{~cm}$ mesh size included one net $11.4 \mathrm{~cm}$. Different letters denote significant differences in CPUE between mesh sizes in each lake-year (Dunnett's $T 3, p \leqslant 0.005)$.

Alabama Department of Conservation and Natural Resources, and the management plan was targeted at increasing forage for predatory fish without adverse effects to other planktivores (Irwin et al., 2003). Schaus et al. (2002) documented a large reduction in older year classes of gizzard shad in Acton Lake, $\mathrm{OH}$, likely due to natural mortality near the end of the typical lifespan. This biomass reduction led to a strong year class that fed on zooplankton and grew five times larger than other age-0 cohorts, with some individuals potentially spawning (elevated gonadosomatic index) the following spring (Schaus et al., 2002). Thus this species has the potential for compensatory growth following a partial removal, but the degree to which the population can increase may depend on factors such as lake productivity, zooplankton density, and the magnitude of spawner reduction.

In Florida lakes, experimental gizzard shad removals in Lakes Denham and Dora yielded somewhat different results. The Lake Denham removal (1990-1992) used haul seines (mesh 8.75-10 cm stretched mesh) to remove well over $90 \%$ of the harvestable (>200 mm TL) 


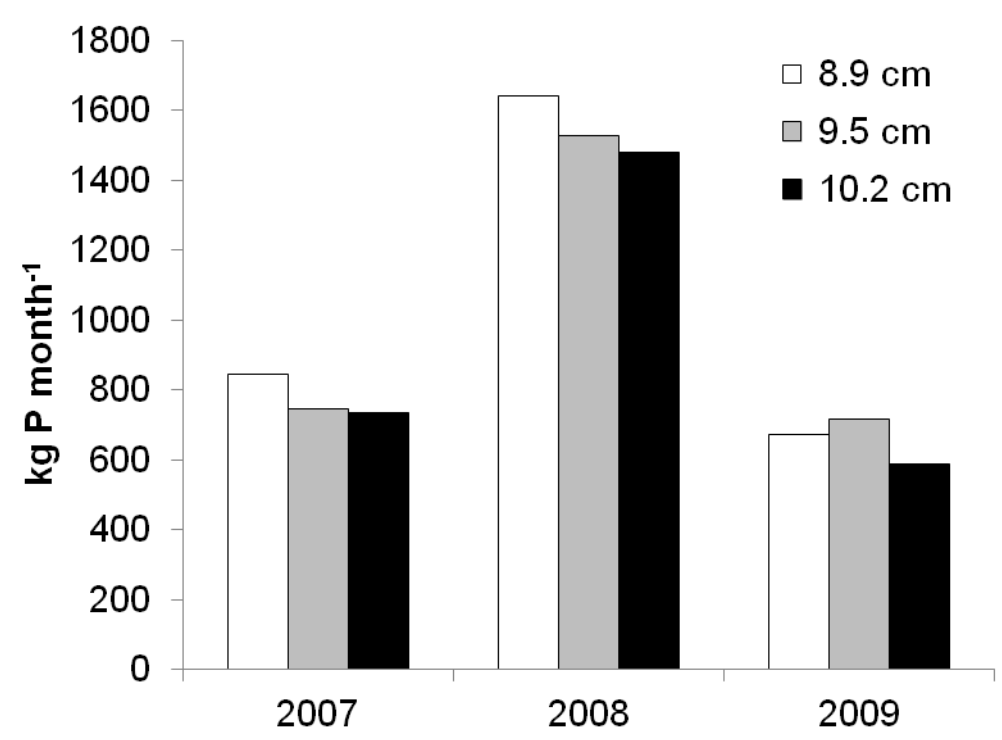

\section{Figure 8}

Effect of mesh size on the reduction in $P$ excretion immediately after the gizzard shad harvests in Lake Apopka during 2007-2009. These calculations reflect the differences in size structure harvested, but assume equivalent biomass harvested by nets of different mesh sizes. The use of $8.9 \mathrm{~cm}$ mesh nets in place of $10.2 \mathrm{~cm}$ mesh nets would increase the nutrient effect by 10.7-15.1\%, due to the harvest of smaller size classes by smaller mesh nets. Differences among years are primarily due to differences in overall harvest.

gizzard shad biomass (Godwin et al., 2011). The 1992 sampling was suspended after only 8 seine hauls, because there were so few fish harvested. The gizzard shad biomass in experimental gill nets remained lower after the cessation of harvest, and water quality parameters (chl a, TP, Secchi depth, TSS, etc.) showed improvements that persisted for at least 3-8 years (Godwin et al., 2011). The Lake Dora fish removal (2005-2006) was conducted to examine the potential density-dependent effects on growth, survival and fecundity following gizzard shad removal. These harvests suppressed the spawner biomass by over $70 \%$ and decreased the total population biomass by 30-40\% (Catalano et al., 2010; Catalano and Allen, 2011a). Following these removals, there was no detectable short-term improvement in water quality (Catalano et al., 2010), and little variation in growth (Catalano and Allen, 2011a). Despite the large reduction in spawner biomass, there was little effect on recruitment to age-1, suggesting substantial density dependent effects on age-0 survival (Catalano and Allen, 2011a). Although the lack of water quality improvement and increased survival of age-0 gizzard shad following harvest in Lake Dora might lead to the conclusion that this harvest was unsuccessful, the purpose of that experimental removal was to gain insight on compensatory effects rather than to improve water quality. Future studies should seek to examine the magnitude of gizzard shad biomass reduction that is necessary to maintain improved water quality over the long term.

Several reviews of European biomanipulations indicate that the removal of $80 \%$ of the total fish (primarily roach, Rutilus rutilus, and bream, Abramis brama) biomass (Hansson et al., 1998; Meijer et al., 1999; Jeppesen et al., 2007) or the removal of over $200 \mathrm{~kg} \cdot \mathrm{ha}^{-1}$ within a three year period (Søndergaard et al., 2008) increases the likelihood of success for a fish removal project. Thus, some authors have recommended that biomanipulation will be most effective in smaller lakes where there is an increased likelihood of removing a large portion of the fish biomass (Meijer et al., 1999; Jeppesen et al., 2007). The SJRWMD removals in Lakes Apopka and Griffin have been smaller on a $\mathrm{kg} \cdot \mathrm{ha}^{-1}$ basis than what was recommended by Søndergaard et al. (2008), partially because of the large size of these lakes (Table I). However, the SJRWMD removals have repeatedly harvested fish over several years in succession, lowering reproduction by larger size classes, and fish harvest remains the cheapest means to remove $P$ from these lakes (SJRWMD, unpublished data). The annual removals reported here ranged from $19.1-121.6 \mathrm{~kg} \cdot \mathrm{ha}^{-1} \cdot \mathrm{yr}^{-1}$ (Table V), and the annual removals from 
Lake Denham (104 ha, $1.4 \mathrm{~m}$ mean depth) were $380 \mathrm{~kg} \cdot \mathrm{ha}^{-1} \cdot \mathrm{yr}^{-1}$ during $1990,88 \mathrm{~kg} \cdot \mathrm{ha}^{-1} \cdot \mathrm{yr}^{-1}$ during 1991, and $30 \mathrm{~kg} \cdot \mathrm{ha}^{-1} \cdot \mathrm{yr}^{-1}$ during 1992 (Godwin et al., 2011). In Lake Apopka, a multipronged management effort has sought to cut external $P$ loading, remove gizzard shad, and remove particulate $P$ via wetland filtration (Coveney et al., 2002, 2005; Schaus et al., 2010). The combination of these approaches has reduced total $P$ by $54 \%$, reduced $\mathrm{Chl} a$ by $37 \%$, and increased Secchi depth by $47 \%$ (Coveney et al., 2005). In Lake Apopka, the water quality improvements likely were most strongly tied to reductions in external nutrient inputs $\left(\sim 38,750 \mathrm{~kg} \mathrm{P} \cdot \mathrm{yr}^{-1}\right)$, which were much larger than effects of the gizzard shad removal (2960 kg.P.yr ${ }^{-1}$ direct removal; $1230-14,820 \mathrm{~kg} \mathrm{P} \cdot \mathrm{yr}^{-1}$ excretion reduction) and wetland filtration (1478-2754 kg P.yr ${ }^{-1}$ ) $P$ effects (Schaus et al., 2010). However, once external $P$ loading has been cut, fish removal remains one of the additional options to potentially improve water quality.

It has been well documented that gizzard shad is dominant only in highly eutrophic lakes (Bachmann et al., 1996; Allen et al., 2000). The multiple stable states hypothesis (Scheffer et al., 1993) predicts that a substantial reduction in external nutrient loading coupled with biomanipulation could shift the ecosystem to a clear water state dominated by macrophytes, which resists the change toward phytoplankton dominance and cyanobacterial blooms. Gizzard shad are less abundant in lakes with lower water column chlorophyll and/or with abundant macrophytes (Allen et al., 2000; Michaletz and Bonneau, 2005). If external nutrient inputs are lowered and fish biomass can be decreased enough, then potentially the lake can be shifted to a clear water state dominated by macrophytes (Scheffer, 2001; Søndergaard et al., 2008), which resists the reestablishment of a high gizzard shad biomass. Thus, it is possible that the reduced productivity of the ecosystem could counteract the tendency of this species to proliferate, potentially maintaining the lake in a macrophyte dominated stable state similar to what was historically documented in Lake Apopka (Schelske et al., 2005). At the least, a substantial fish reduction could increase the time interval between large scale fish removal projects. Future studies should examine the degree of gizzard shad biomass reduction that is necessary to attain long term water quality benefits and enhancement of macrophytes. Decisions about whether or not to utilize biomanipulation efforts should consider not only the duration, cost and the likelihood of bycatch, but also the cost-effectiveness of nutrient removal in biomass and the likelihood of achieving the objectives of a large fish reduction and a shift to a stable, clear water state dominated by macrophytes.

\section{ACKNOWLEDGEMENTS}

Olivia Thomas assisted with experimental and commercial gill net sampling. Liz Martin, Kevin Wright, Brian Sparks, Jim Peterson and the Lake Apopka field station staff provided support in the field. PPB labs analyzed all water samples. Roxanne Conrow, Mike Allen, Matt Catalano and Loreto De Brabandere, and two anonymous reviewers provided comments on earlier drafts of this manuscript. This work was funded by the St. Johns River Water Management District (contract grant SK933AA to M.H. Schaus).

\section{REFERENCES}

Allen M.S., Hoyer M.V. and Canfield D.E., Jr., 2000. Factors related to gizzard shad and threadfin shad occurrence and abundance in Florida lakes. J. Fish Biol., 57, 291-302.

Bachmann R.W., Jones B.L., Fox D.D., Hoyer M., Bull L.A. and Canfield D.E., Jr., 1996. Relations between trophic state indicators and fish in Florida (USA) lakes. Can. J. Fish. Aquat. Sci., 53, 842855.

Brabrand Å., Faafeng B.A. and Nilssen J.P.M., 1990. Relative importance of phosphorus supply to phytoplankton production: fish excretion versus external loading. Can. J. Fish. Aquat. Sci., 47, 364-372.

Carpenter S.R., Kitchell J.F., Hodgson J.R., Cochran P.A., Elser J.J., Elser M.M., Lodge D.M., Kretchmer D. and He X., 1987. Regulation of lake primary productivity by food web structure. Ecology, 68, 1863-1876. 
Catalano M.J. and Allen M.S., 2011a. A whole-lake density reduction to assess compensatory responses of gizzard shad Dorosoma cepedianum. Can. J. Fish. Aquat. Sci., 68, 955-968.

Catalano M.J. and Allen M.S., 2011b. Exploring strategies for gizzard shad removal that account for compensatory density dependence and uncertainty. N. Am. J. Fish. Manage., 31, 1153-1162.

Catalano M.J., Allen M.S., Schaus M.H., Buck D.G. and Beaver J.R., 2010. Evaluating short-term effects of omnivorous fish removal on water quality and zooplankton at a subtropical lake. Hydrobiologia, 655, 159-169.

Coveney M.F., Lowe E.F., Battoe L.E., Marzolf E.R. and Conrow R., 2005. Response of a eutrophic shallow subtropical lake to reduced nutrient loading. Freshw. Biol., 50, 1718-1730. and erratum, Freshw. Biol., 50, 2167.

Coveney M.F., Stites D.L., Lowe E.F., Battoe L.E. and Conrow R., 2002. Nutrient removal from eutrophic lake water by wetland filtration. Ecol. Eng., 19, 141-159.

Devries D.R. and Stein R.A., 1990. Manipulating shad to enhance sport fisheries in North America: an assessment. N. Am. J. Fish. Manage., 10, 209-223.

Drenner R.W. and Hambright K.D., 1999. Review: biomanipulation of fish assemblages as a lake restoration technique. Arch. Hydrobiol., 146, 129-165.

Fulton R.S. III, 1995. External nutrient budget and trophic state modeling for lakes in the Upper Ocklawaha River Basin. St. Johns River Water Management District Technical Publication SJ95-6. http://www.sjrwmd.com/technicalreports/pdfs/TP/SJ95-6.pdf [accessed 1 July 2013].

Fulton R.S., III and Smith D., 2008. Development of phosphorus load reduction goals for seven lakes in the upper Ocklawaha River Basin, Florida. Lake Reservoir Manage., 24, 139-154.

Gido K.B., 2002. Interspecific comparisons and the potential importance of nutrient excretion by benthic fishes in a large reservoir. Trans. Am. Fish. Soc., 131, 260-270.

Godwin W., Coveney M., Lowe E. and Battoe L., 2011. Improvements in water quality following biomanipulation of gizzard shad (Dorosoma cepedianum) in Lake Denham, Florida. Lake Reservoir Manage., 27, 287-297.

Hall R.O., Jr., Koch B.J., Marshall M.C., Taylor B.W. and Tronstad L.M., 2007. How body size mediates the role of animals in nutrient cycling in aquatic ecosystems. In: Hildrew A.G., Raffaelli D.G. and Edmonds-Brown R. (eds.), Body size: The structure and function of aquatic ecosystems, Cambridge University Press, Cambridge, UK, 286-305.

Hansson L.A., Annadotter H., Bergman E., Hamrin S.F., Jeppesen E., Kairesalo T., Luokkanen E., Nilsson P-Å, Søndergaard M. and Strand J., 1998. Biomanipulation as an application of foodchain theory: constraints, synthesis, and recommendations for temperate lakes. Ecosystems, 1 , 558-574.

Higgins K.A., Vanni M.J. and Gonzalez M.J., 2006. Detritivory and the stoichiometry of nutrient cycling by a dominant fish species in lakes of varying productivity. Oikos, 114, 419-430.

Irwin B.J., DeVries D.R. and Kim G.W., 2003. Responses to gizzard shad recovery following selective treatment in Walker County Lake, Alabama, 1996-1999. N. Am. J. Fish. Manage., 23, 1225-1237.

Jeppesen E., Meerhoff M., Jacobsen B.A., Hansen R.S., Søndergaard M., Jensen J.P., Lauridsen T.L., Mazzeo N. and Branco C.W.C., 2007. Restoration of shallow lakes by nutrient control and biomanipulation - the successful strategy varies with lake size and climate. Hydrobiologia, 581, 269-285.

Kim G.W. and DeVries D.R., 2000. Effects of a selectively reduced gizzard shad population on trophic interactions and age-0 fishes in Walker County Lake, Alabama. N. Am. J. Fish. Manage., 20, 860-872.

Kosten S., Lacerot G., Jeppesen E., da Motta Marques D., van Nes E., Mazzeo N. and Scheffer M., 2009. Effects of submerged vegetation on water clarity across climates. Ecosystems, 12, 1117-1129.

Lamarra V.A., Jr., 1975. Digestive activities of carp as a major contributor to the nutrient loading of lakes. Verh. Int. Ver. Theor. Angew. Limnol., 19, 2461-2468.

Matsuzaki S.S., Usio N., Takamura N. and Washitani I., 2007. Effects of common carp on nutrient dynamics and littoral community composition: roles of excretion and bioturbation. Fundam. Appl. Limnol., 168, 27-38.

Meijer M.-L., de Bois I., Scheffer M., Portielje R. and Hosper H., 1999. Biomanipulation in shallow lakes in the Netherlands: an evaluation of 18 case studies. Hydrobiologia, 408-409, 13-30. 
Michaletz P.H. and Bonneau J.L., 2005. Age-0 gizzard shad abundance is reduced in the presence of macrophytes: implications for interactions with bluegills. Trans. Am. Fish. Soc., 134, 149-159.

Pilati A. and Vanni M.J., 2007. Ontogeny, diet shifts, and nutrient stoichiometry in fish. Oikos, 116, 1663-1674.

Schaus M.H. and Vanni M.J., 2000. Effects of omnivorous gizzard shad on phytoplankton and nutrient dynamics: role of sediment feeding and fish size. Ecology, 81, 1701-1719.

Schaus M.H., Vanni M.J., Wissing T.E., Bremigan M.T., Garvey J.E. and Stein R.A., 1997. Nitrogen and phosphorus excretion by detritivorous gizzard shad (Dorosoma cepedianum) in a reservoir ecosystem. Limnol. Oceanogr., 42, 1386-1397.

Schaus M.H., Vanni M.J. and Wissing T.E., 2002. Biomass-dependent diet shifts in omnivorous gizzard shad: implications for growth, food web, and ecosystem effects. Trans. Am. Fish. Soc., 131, 40-54.

Schaus M.H., Godwin W., Battoe L., Coveney M., Lowe E., Roth R., Hawkins C., Vindigni M., Weinberg C. and Zimmerman A., 2010. Impact of the removal of gizzard shad (Dorosoma cepedianum) on nutrient cycles in Lake Apopka, Florida. Freshw. Biol., 55, 2401-2413.

Scheffer M., 2001. Alternative attractors of shallow lakes. TheScientificWorldJOURNAL, 1, 254-263.

Scheffer M., Hosper S.H., Meijer M-L., Moss B. and Jeppesen E., 1993. Alternative equilibria in shallow lakes. Trends Ecol. Evol., 8, 275-279.

Schelske C.L., Lowe E.F., Battoe L.E., Brenner M., Coveney M.F. and Kenney W.F., 2005. Abrupt biological response to hydrologic and land-use changes in Lake Apopka, Florida, USA. Ambio, 34, 192-198.

Schmidt-Nielsen K., 1975. Animal physiology, adaptation, and environment, Cambridge University Press, Cambridge, UK, 699 p.

Søndergaard M., Liboriussen L., Pedersen A.R. and Jeppesen E., 2008. Lake restoration by fish removal: short- and long-term effects in 36 Danish Lakes. Ecosystems, 11, 1291-1305.

Vanni M.J., 2002. Nutrient cycling by animals in freshwater ecosystems. Annu. Rev. Ecol. Syst., 33, 341-370.

Vanni M.J. and Layne C.D., 1997. Nutrient recycling and herbivory as mechanisms in the "top-down" effect of fish on phytoplankton in lakes. Ecology, 78, 21-40.

Wen Y.H. and Peters R.H., 1994. Empirical models of phosphorus and nitrogen excretion rates by zooplankton. Limnol. Oceanogr., 39, 1669-1679. 